\title{
The Effect of Job Characteristics of Life Managers for Elderly People Living Alone on Quality of Life
}

\author{
Dae-Ju Lee ${ }^{1}$ and Sung-je Cho ${ }^{2 *}$ \\ ${ }^{1}$ (Ph.D. course/doctorate course) Dept. Department of Regional and Welfare \\ Administration Department, Dongbang Culture Graduate Univ., 28 Sungbok-Ro, \\ Sungbokdong, Seoul, 02838, Korea \\ ${ }^{2 *}$ Professor, Department Department of Regional and Welfare Administration \\ Department, Dongbang Culture Graduate Univ., 28 Sungbok-Ro, Sungbokdong, \\ Seoul, 02838, Korea \\ ${ }^{1}$ jesus9106@naver.com, ${ }^{2 *}$ chosj715@daum.net
}

\begin{abstract}
The purpose of this study is to investigate the effect of job characteristics of life managers for elderly people living alone on quality of life. The study was conducted on 180 life managers for elderly people living alone in Daegu Metropolitan City. Frequency analysis, reliability analysis, and correlation analysis were performed using the SPSS 22.0 program. Multiple regression analysis was performed on causality between variables. The results of this study were as follows: First, among the sub-factors of job characteristics of life managers for elderly people living alone, job diversity and job autonomy factors had significant effects on the physical quality of life. Second, it was confirmed that only the job autonomy factor had a significant influence on the mental quality of life among sub-factors of perceived job characteristics. Third, among the sub-factors of perceived job characteristics of life managers for elderly people living alone, job diversity and job autonomy factors have significant effects on socioeconomic quality of life. This study is expected to be basic data for establishing a better working environment to improve the quality of life managers for elderly people living alone.
\end{abstract}

Keywords: Elderly people living alone, Life managers for elderly people living alone, Job characteristics, Quality of life

\section{Introduction}

\subsection{The need for research}

The transition to an aging society has begun to emphasize the roles and responsibilities of the nation in elderly care, and social care services have emerged. In addition, elderly people are exposed to suicide because of solitude and depression due to economic weakness, role loss, and health problems. As the family is differentiated, the unity of the family is decreased and the number of the elderly living alone is increasing due to the death of their spouse or

Article history:

Received (March 27, 2019), Review Result (April 26, 2019), Accepted (May 25, 2019) 
economic reasons [1]. The elderly living alone has been reported to have lower health status, depression, and lower quality of life than elderly people living with family members [2]. The elderly living alone who have these difficulties have a possibility that the health problems they experience in everyday life become more severe and, therefore, social measures are required.

Therefore, the national or municipal governments are carrying out basic care services for the elderly to make the elderly living alone to take protective measures such as visiting medical care services and safety confirmation services (Article 27-2 of the Elderly Welfare Act). The life managers for elderly people living alone are the main workforce of this project and their main job is to provide emotional support to elderly people living alone through phone calls twice a week and weekly visits [3]. Nonetheless, life managers for the elderly living alone are more likely to experience stress due to poor working environment, role conflict, and low social cognition when compared with other occupational workers [4].

In general, the psychological capital of the service provider has a positive effect on the provision of high-quality service to the elderly living alone, which is an important factor in service quality. Based on these findings, it is necessary to find ways to improve the psychological capital of life managers for the elderly living alone to provide better quality service to the elderly living alone. This is because the psychological capital of life managers for the elderly living alone is a positive factor for job satisfaction, whereas it is a negative factor for job stress [5]. The most important variable in the service of medical care is the direct quality of life. And, in the relationship between internal behavior and service quality of caregivers, it was confirmed that there is a negative correlation between the static correlation and the surface behavior and service quality [6]. In addition, there was a positive correlation between service quality and job attitude of home care nursing home caregivers, and it was found that job attitude had a significant mediating effect on the relationship between organizational environment factors and service quality [7].

On the other hand, previous studies have shown that the job environment of caregivers is a factor affecting job exhaustion, job stress, and job satisfaction [8].

The results of this study suggest that there is a need to study the effects of job characteristics on the quality of life managers for elderly people living alone. Therefore, this study aims to provide basic data for the stress and exhaustion prevention of life managers for elderly people living alone by clarifying the influence of job characteristics on the quality of life.

\subsection{Research objectives}

The purpose of this study is to analyze the effect of the job characteristics of life managers for elderly people living alone on quality of life. The research questions are as follows.

First, what is the effect of job characteristics of life managers for elderly people living alone on the physical quality of life?

Second, what is the effect of job characteristics of life managers for elderly people living alone on the mental quality of life?

Third, what is the effect of job characteristics of life managers for elderly people living alone on socioeconomic quality of life? 


\section{Research methods and results}

\subsection{Reliability of major variables}

As a result of the reliability test of each variable used in this study, the reliability of job diversity .726, job identity .692, job importance .672 , job autonomy .755 total reliability. The reliability of the quality of life was found to be as follows: physical quality of life .867 , mental quality of life .833 , socioeconomic quality of life .810 total reliability .886 . The results of the reliability analysis are shown in [Table 1].

Table 1. Reliability of major variables

\begin{tabular}{|c|c|c|c|c|}
\hline \multicolumn{2}{|c|}{ Category } & \multirow{2}{*}{$\begin{array}{c}\text { Question } \\
\text { Numbar }\end{array}$} & \multicolumn{2}{|c|}{ Cronbach's $\alpha$} \\
\hline \multirow{4}{*}{$\begin{array}{c}\text { Job } \\
\text { Characteristics }\end{array}$} & Job Variety & & .726 & \multirow{4}{*}{.743} \\
\hline & Job Identity & 3 & .692 & \\
\hline & Job Importance & 3 & .672 & \\
\hline & Job Autonomy & 3 & .755 & \\
\hline \multirow{3}{*}{ Quality of Life } & $\begin{array}{c}\text { Physical Quality of } \\
\text { I ifo }\end{array}$ & 5 & .867 & \multirow{3}{*}{.886} \\
\hline & $\begin{array}{c}\text { Mental Quality of } \\
\text { I if॰ }\end{array}$ & 5 & .833 & \\
\hline & $\begin{array}{l}\text { Socioeconomic } \\
\text { Quality of Life }\end{array}$ & 5 & .810 & \\
\hline
\end{tabular}

\subsection{Demographic characteristics}

[Table 2] shows the results of the demographic characteristics of the elderly living careers living alone. The sex was 180 women (100.0\%). The age of the patients in their 50s or older is $129(71.7 \%)$, which is larger than the number of patients in their 40 s or older $(28.3 \%)$. In the case of married status, $178(98.9 \%)$ were married and 68 were unmarried. Religouspeople are $112(62.2 \%)$ and non-religious people are 68 (37.8\%). In the working experience, $59(32.8 \%)$ of the respondents were found to have the most than one year and less than two years.

\subsection{Technical statistics on key variables}

[Table 3] shows the results of the descriptive statistics on the main variables of this study. Job importance $(M=3.80)$ was the highest, and job identity $(M=3.65)$, job autonomy $(M=$ $3.62)$, and job diversity $(\mathrm{M}=3.44)$ were all above average. For sub-factors of quality of life, the quality of mental life $(\mathrm{M}=3.78)$ was the highest, and both physical $(\mathrm{M}=3.68)$ and socioeconomic $(\mathrm{M}=3.63)$ quality of life are above average.

\subsection{Correlation between key variables}

As a result of examining the relationship between job characteristics and the quality of life of the elderly living careers living alone, the sub-factors of job characteristics, such as job diversity and job identity $(\mathrm{r}=.547, \mathrm{p}<.01)$, job identity, and job importance $(\mathrm{r}=.611, \mathrm{p}<.01)$, physical and mental quality of life $(\mathrm{r}=.680, \mathrm{p}<.01)$ showed a somewhat higher positive correlation. On the other hand, the quality of life and socioeconomic quality of life $(r=.720$, 
$\mathrm{p}<.01)$, mental quality of life, and socioeconomic quality of life $(\mathrm{r}=.768, \mathrm{p}<.01)$ showed a high positive correlation. The results of the correlation analysis between the main variables of the study subjects are shown in [Table 4].

Table 2. Demographic characteristics

\begin{tabular}{|c|c|c|c|}
\hline \multirow{2}{*}{\multicolumn{2}{|c|}{ Category }} & \multicolumn{2}{|c|}{ Total $(\mathrm{N}=180)$} \\
\hline & & Frequency & Percentage $(\%)$ \\
\hline \multirow{2}{*}{ Gender } & Male & 0 & 0.0 \\
\hline & Female & 180 & 100.0 \\
\hline \multirow{2}{*}{ Age } & Below the $40 \mathrm{~s}$ & 51 & 28.3 \\
\hline & Over the $50 \mathrm{~s}$ & 129 & 71.7 \\
\hline \multirow{2}{*}{ Marital Status } & Single & 2 & 1.1 \\
\hline & Married & 178 & 98.9 \\
\hline \multirow{2}{*}{ Religion } & Religious & 112 & 62.2 \\
\hline & Non-religious & 68 & 37.8 \\
\hline \multirow{5}{*}{ Work Experience } & Between 1-2 years & 59 & 32.8 \\
\hline & Between 2-4 years & 24 & 13.3 \\
\hline & Between $4-6$ years & 58 & 32.2 \\
\hline & Between $6-8$ years & 14 & 7.8 \\
\hline & Over 8 years & 25 & 13.9 \\
\hline
\end{tabular}

Table 3. Technical statistics on key variables

\begin{tabular}{|c|c|c|c|c|c|c|}
\hline \multicolumn{2}{|c|}{ Category } & N & $\begin{array}{c}\text { Minimum } \\
\text { Value }\end{array}$ & $\begin{array}{c}\text { Maximum } \\
\text { Value }\end{array}$ & M & SD \\
\hline \multirow{4}{*}{$\begin{array}{c}\text { Job } \\
\text { Characteristics }\end{array}$} & Job Variety & 180 & 1.00 & 4.33 & 3.44 & .54 \\
\cline { 2 - 7 } & Job Identity & 180 & 2.00 & 5.00 & 3.65 & .55 \\
\cline { 2 - 7 } & $\begin{array}{c}\text { Job } \\
\text { Imnnrtance }\end{array}$ & 180 & 1.00 & 5.00 & 3.80 & .54 \\
\cline { 2 - 7 } $\begin{array}{c}\text { Quality of } \\
\text { Life }\end{array}$ & Job Autonomy & 180 & 2.00 & 5.00 & 3.62 & .65 \\
\cline { 2 - 7 } & Physical & 180 & 2.00 & 5.00 & 3.68 & .50 \\
\cline { 2 - 7 } & Socioeconomic & 180 & 2.00 & 5.00 & 3.63 & .57 \\
\hline
\end{tabular}

\subsection{The effect of job characteristics of life managers for elderly people living alone on the physical quality of life}

[Table 5] shows the results of examining the effects of job characteristics of living alone with elderly caregivers on the physical quality of life. Multiple regression analysis was 
performed to examine the effect of job characteristics on the physical quality of life. As a result, the R2 square value, which means the explanatory power of job characteristics on the physical quality of life, is .103, which shows the regression model to be $10.3 \%$ of the total variation. The variance analysis of the model showed that the estimated regression model $(\mathrm{F}=$ $5.003, \mathrm{p}<.000)$ was statistically significant. In terms of sub-factors, job autonomy $(\beta=.149$, $\mathrm{p}<.05)$ showed a significant influence on the physical quality of life. This implies that the higher the factor of job autonomy, the higher the quality of physical life.

Table 4. Correlation between key variables

\begin{tabular}{|c|c|c|c|c|c|c|c|c|}
\hline \multirow{2}{*}{\multicolumn{2}{|c|}{ Category }} & \multicolumn{4}{|c|}{ Job Characteristics } & \multicolumn{3}{|c|}{ Quality of Life } \\
\hline & & \multirow{2}{*}{$\frac{\text { Variety }}{1}$} & \multirow{2}{*}{ Identity } & \multirow{2}{*}{ Importance } & \multirow{2}{*}{ Autonomy } & \multirow{2}{*}{ Physical } & \multirow{2}{*}{ Mental } & \multirow{2}{*}{ Socioeconomic } \\
\hline \multirow{4}{*}{$\begin{array}{c}\text { Job } \\
\text { Characteristics }\end{array}$} & Job Variety & & & & & & & \\
\hline & Job Identity & $.547 * *$ & 1 & & & & & \\
\hline & $\begin{array}{c}\text { Job } \\
\text { Importance }\end{array}$ & $.359 * *$ & $.611 * *$ & 1 & & & & \\
\hline & Job Autonomy & $.229 * *$ & $.474 * *$ & $.358 * *$ & 1 & & & \\
\hline \multirow{3}{*}{$\begin{array}{l}\text { Quality of } \\
\text { Life }\end{array}$} & Physical & $.227 * *$ & $.276 * *$ & $.242 * *$ & $.254 * *$ & 1 & & \\
\hline & Mental & $.295 * *$ & $.303 * *$ & $.339 * *$ & $.297 * *$ & $.680 * *$ & 1 & \\
\hline & Socioeconomic & $.315^{* *}$ & $.296 * *$ & $.271 * *$ & $.229 * *$ & $.720 * *$ & $.768 * *$ & 1 \\
\hline
\end{tabular}

Table 5. The effect of job characteristics of life managers for elderly people living alone on the physical quality of life

\begin{tabular}{|c|c|c|c|c|c|c|c|}
\hline \multirow{2}{*}{$\begin{array}{l}\text { Dependent } \\
\text { Variable }\end{array}$} & \multirow{2}{*}{$\begin{array}{l}\text { Independent } \\
\text { Variable }\end{array}$} & \multicolumn{2}{|c|}{$\begin{array}{c}\text { Non- } \\
\text { standardization }\end{array}$} & \multirow{2}{*}{$\begin{array}{c}\begin{array}{c}\text { Standardization } \\
\text { Factor }\end{array} \\
\beta\end{array}$} & \multirow{2}{*}{$\mathrm{t}$} & \multirow{2}{*}{$\mathrm{p}$} & \multirow{2}{*}{$\begin{array}{l}\text { Tolerance } \\
\text { limit }\end{array}$} \\
\hline & & B & $\begin{array}{l}\text { Standard } \\
\text { Error }\end{array}$ & & & & \\
\hline \multirow{5}{*}{$\begin{array}{c}\text { Physical } \\
\text { Quality of } \\
\text { Life }\end{array}$} & Constant & 2.473 & .315 & & $7.861 * * *$ & .000 & \\
\hline & Job Variety & -.029 & .081 & -.030 & -.354 & .724 & .698 \\
\hline & Job Identity & .146 & .098 & .160 & 1.492 & .138 & .448 \\
\hline & Job Importance & .095 & .085 & .102 & 1.118 & .265 & .619 \\
\hline & Job Autonomy & .115 & .063 & .149 & $1.819 *$ & .021 & .766 \\
\hline
\end{tabular}

$R^{2}=.103$, Modified $R^{2}=.082, F=5.003, P=.000$, Durbin-Watson $=1.593$ $* p<.05, * * p<.01, * * * p<.001$

\subsection{The effect of job characteristics of life managers for elderly people living alone on socioeconomic quality of life}

The effects of job characteristics of living alone elderly people on the mental quality of life are shown in Table 6 . The R2 value, which indicates the explanatory power of job characteristics on the quality of mental life, is .161, which shows the regression model as $16.1 \%$ of the total variation. The variance analysis of the model showed that the estimated regression model $(\mathrm{F}=8.405, \mathrm{p}<.000)$ was statistically significant. In terms of the sub-factors of job characteristics, job importance $(\beta=-.231, p<.05)$ and job autonomy $(\beta=.174, p<.05)$ appear. This means that the higher the job importance factor and the job autonomy factor, the higher the quality of mental life. 


\subsection{The effect of job characteristics on the socioeconomic quality of life of elderly living caregivers}

The effects of the job characteristics of the elderly living careers on the socioeconomic quality of life are shown in Table 7 . As a result, the R2 value, the explanatory power of job characteristics on socioeconomic quality of life, is .112, which accounts for $11.2 \%$ of the total variation. The variance analysis of the model showed that the estimated regression model $(\mathrm{F}=$ $5.498, \mathrm{p}<.000)$ was statistically significant. Job identity $(\beta=-.201, \mathrm{p}<.05)$ was found to have a significant influence on the socioeconomic quality of life. This implies that socioeconomic quality of life is higher as the factor of job identity among sub-factors of job characteristics of elderly living careers living alone.

Table 6. The effect of job characteristics of life managers for elderly people living alone on socioeconomic quality of life

\begin{tabular}{|c|c|c|c|c|c|c|c|}
\hline \multirow{2}{*}{$\begin{array}{l}\text { Dependent } \\
\text { Variable }\end{array}$} & \multirow{2}{*}{$\begin{array}{c}\text { Independent } \\
\text { Variable }\end{array}$} & \multicolumn{2}{|c|}{$\begin{array}{c}\text { Non- } \\
\text { standardization } \\
\text { Factor }\end{array}$} & \multirow{2}{*}{$\begin{array}{c}\begin{array}{c}\text { Standardization } \\
\text { Factor }\end{array} \\
\beta\end{array}$} & \multirow[t]{2}{*}{$\mathrm{t}$} & \multirow{2}{*}{$\mathrm{p}$} & \multirow{2}{*}{$\begin{array}{c}\text { Tolerance } \\
\text { limit }\end{array}$} \\
\hline & & B & $\begin{array}{l}\text { Standard } \\
\text { Error }\end{array}$ & & & & \\
\hline \multirow{5}{*}{$\begin{array}{l}\text { Socioeconomic } \\
\text { Quality of Life }\end{array}$} & Constant & 2.252 & .355 & & $6.354 * * *$ & .000 & \\
\hline & Job Variety & -.071 & .091 & -.067 & -.781 & .436 & .698 \\
\hline & Job Identity & .208 & .110 & .201 & $1.891^{*}$ & .040 & .448 \\
\hline & $\begin{array}{c}\text { Job } \\
\text { Importance }\end{array}$ & .143 & .096 & .136 & 1.497 & .136 & .619 \\
\hline & $\begin{array}{c}\text { Job } \\
\text { Autonomy }\end{array}$ & .088 & .071 & .101 & 1.236 & .218 & .766 \\
\hline
\end{tabular}

\section{Conclusion}

The purpose of this study was to analyze the effects of job characteristics of life managers for elderly people living alone on quality of life. The following discussion is based on the results of the analysis.

First, among the sub-factors of job characteristics perceived by life managers for elderly people living alone, the job autonomy factor showed a significant influence on the physical quality of life.

Second, among the sub-factors of job characteristics perceived by life managers for elderly people living alone, job importance and job autonomy factors have a significant influence on the mental quality of life.

Third, among the sub-factors of job characteristics perceived by life managers for elderly people living alone, the job identity factor had a significant influence on the socioeconomic quality of life. 
Table 7. The effect of job characteristics on the socioeconomic quality of life of elderly living caregivers

\begin{tabular}{|c|c|c|c|c|c|c|c|}
\hline \multirow{2}{*}{$\begin{array}{l}\text { Dependent } \\
\text { variable }\end{array}$} & \multirow{2}{*}{$\begin{array}{l}\text { Independent } \\
\text { variable }\end{array}$} & \multicolumn{2}{|c|}{$\begin{array}{c}\text { Non-standardization } \\
\text { factor }\end{array}$} & \multirow{2}{*}{$\begin{array}{c}\begin{array}{c}\text { Standardization } \\
\text { factor }\end{array} \\
\beta\end{array}$} & \multirow{2}{*}{$\mathrm{t}$} & \multirow{2}{*}{$\mathrm{p}$} & \multirow{2}{*}{$\begin{array}{l}\text { Tolerance } \\
\text { Limit }\end{array}$} \\
\hline & & B & $\begin{array}{l}\text { Standard } \\
\text { error }\end{array}$ & & & & \\
\hline \multirow{5}{*}{$\begin{array}{l}\text { Socio- } \\
\text { economic } \\
\text { Quality of } \\
\text { life }\end{array}$} & Constant & 2.252 & .355 & & $6.354 * * *$ & .000 & \\
\hline & Job Variety & -.071 & .091 & -.067 & -.781 & .436 & .698 \\
\hline & Job identity & .208 & .110 & .201 & $1.891^{*}$ & .040 & .448 \\
\hline & $\begin{array}{c}\text { Job } \\
\text { Importance }\end{array}$ & .143 & .096 & .136 & 1.497 & .136 & .619 \\
\hline & $\begin{array}{c}\text { Job } \\
\text { autonomy }\end{array}$ & .088 & .071 & .101 & 1.236 & .218 & .766 \\
\hline
\end{tabular}

$R^{2}=.112$, Modified $R^{2}=.091$

$F=5.498, P=.000$, Durbin - Watson $=1.580$

${ }^{*} p<.05, * * p<.01, * * * p<.001$

As discussed above, the need for life managers for elderly people living alone is increasing to provide for the elderly living alone. Therefore, in this study, it is meaningful to investigate the relationship between job characteristics and quality of life perceived by the life managers for elderly people living alone. Based on the results of this study, it is necessary to develop a program that can improve job characteristics and quality of life managers for elderly people living alone. In the future, an in-depth research is needed on the satisfaction of life managers for the elderly living alone.

\section{Acknowledgments}

Thanks to professor Sung-je Cho who instructed me, the family who is always with me, and the welfare center staff who gave me a theoretical background in this filed.

\section{References}

[1] J. C. Noh and Z. K. Ko, "Current status and problems of support policies and legal improvement devices for the aged living alone," International Journal of Contents, vol.13, no.1, pp.257-268, (2013)

[2] K. B. Kim, Y. J. Lee, and S. H. Sok, "A comparative study on health status, depression, and quality of life between the elderly living with family and the elderly living alone," Korean Journal of Adult Nursing, vol.20, no.5, pp.765-777, (2008)

[3] KOSIS, Korean Statistical Information Service, (2017)

[4] Y. H. Won and J. K. Park, "The influence of job stress of life manager for elderly people living alone on job satisfaction," Journal of Community Welfare, vol.49, pp.403-427, (2014)

[5] C. Y. Lee, J. Y. Song, Y. S. Park, "The influence of psychological capital of solitary elderly care manager on job satisfaction," The Social Science Research Institute, vol.33, no.3, pp.47-72, (2017)

[6] Y. S. Rhee, M. S. Song, and J. H. Park, "Effect of long-term care worker's emotional labor on service quality of long-term care facility," Journal of the Korea Academia-Industrial Cooperation Society, vol.18, no.10, pp.336-343, (2017)

[7] S. L. Cho and S. G. Kim, "A research for the relationship between associated activities of home care workers and the quality of the service," Journal of Public Society, vol.5, no.3, pp.163-191, (2015) 
The Effect of Job Characteristics of Life Managers for Elderly People Living Alone on Quality of Life

[8] J. Y. Mo and Y. S. Kang, "The effect of job stress and burnout by job environment of caregivers on job satisfaction," Journal of the Korea Academia-Industrial Cooperation Society, vol.11, no.10, pp.3688-3699, (2010)

\section{Authors}

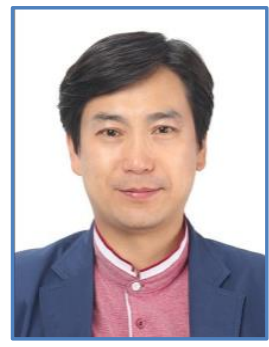

Dae-Ju Lee

2010-present, Professor, Daegu Catholic University and Graduate School 